\title{
Treatment and Valorization of Palm Oil Mill Effluent through Production of Food Grade Yeast Biomass
}

\author{
Joy O. Iwuagwu and J. Obeta Ugwuanyi \\ Department of Microbiology, University of Nigeria, Nsukka 41001, Nigeria \\ Correspondence should be addressed to J. Obeta Ugwuanyi; jerry.ugwuanyi@unn.edu.ng
}

Received 30 July 2014; Accepted 17 September 2014; Published 25 September 2014

Academic Editor: Milva Pepi

Copyright ( 2014 J. O. Iwuagwu and J. O. Ugwuanyi. This is an open access article distributed under the Creative Commons Attribution License, which permits unrestricted use, distribution, and reproduction in any medium, provided the original work is properly cited.

\begin{abstract}
Palm oil mill effluent (POME) is high strength wastewater derived from processing of palm fruit. It is generated in large quantities in all oil palm producing nations where it is a strong pollutant amenable to microbial degradation being rich in organic carbon, nitrogen, and minerals. Valorization and treatment of POME with seven yeast isolates was studied under scalable conditions by using POME to produce value-added yeast biomass. POME was used as sole source of carbon and nitrogen and the fermentation was carried out at $150 \mathrm{rpm}, 28 \pm 2^{\circ} \mathrm{C}$ using an inoculum size of $1 \mathrm{~mL}$ of $10^{6}$ cells. Yeasts were isolated from POME, dump site, and palm wine. The POME had chemical oxygen demand (COD) $114.8 \mathrm{gL}^{-1}$, total solid $76 \mathrm{gL}^{-1}$, total suspended solid (TSS) $44 \mathrm{gL}^{-1}$ and total lipid $35.80 \mathrm{gL}^{-1}$. Raw POME supported accumulation of $4.42 \mathrm{gL}^{-1}$ dry yeast with amino acid content comparable or superior to the FAO/WHO standard for feed use SCP. Peak COD reduction (83\%) was achieved with highest biomass accumulation in $96 \mathrm{~h}$

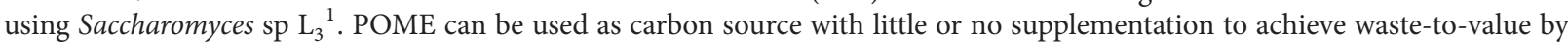
producing feed grade yeast with reduction in pollution potential.
\end{abstract}

\section{Introduction}

Palm oil is the most widely consumed vegetable oil and accounts for about $33 \%$ of total vegetable oil production in the world [1]. Global palm oil production has been dominated by Indonesia and Malaysia and to a lesser extent by Colombia, Thailand, and Nigeria. Combined, these countries produce over $93 \%$ of global palm oil output $[2,3]$. Nigeria is currently the fifth leading producer with over 930,000 metric tons annually [4]. The palm oil industry in Nigeria is a major agroenterprise especially in the southern parts where palm trees grow in the wild and in plantations [5]. About $80 \%$ of the palm oil industry in Nigeria is dominated by smallholders who typically use manual equipment and, to a lesser extent, semimechanized processors for processing palm fruit $[2,3]$. Processing of palm fruit in both methods employs large volumes of water. This results in the production of copious volumes of the liquid waste known as palm oil mill effluent (POME) $[6,7]$. Estimates of the volume of POME produced per litre of palm oil extracted from palm fruits are few and variable. This is occasioned by several variables including differences in the efficiencies of the different processes and nature of the fruit. Manual processes appear to be the least efficient in terms of volume of POME generated, with excess of 10 litres of POME being generated for each litre of oil produced in some instances. Ohimain and Izah [8] reported that 72-80 liters of water are required to process one ton of fresh fruit bunches in the semimechanized process. Of these, $72-75 \%$ ends up as POME.

POME is a high strength pollutant with a low $\mathrm{pH}$ (due to the organic and free fatty acids arising from partial degradation of palm fruits before processing). The characteristics of POME depend on the quality of the raw material and the production processes [9], but it typically contains large amounts of total solids $\left(40,500-75000 \mathrm{mgL}^{-1}\right)$ and oil and grease (2000-8300 $\left.\mathrm{mLL}^{-1}\right)$. Its suspended solids content is in the range of $18,000-47,000 \mathrm{mgL}^{-1}$, total nitrogen in the range of $400-800 \mathrm{mgL}^{-1}$, while the ash content is between 3000 $42000 \mathrm{mgL}^{-1}$ [10]. POME has very high biochemical oxygen demand (BOD) and chemical oxygen demand (COD) in the range of $25,000-54,000 \mathrm{mgL}^{-1}$ and 50,000 to > 
$100,000 \mathrm{mgL}^{-1}$, respectively. These values are 100 times more than that of municipal sewage [11-14].

No matter how effective the method of processing, POME discharged from a mill is objectionable and could pollute streams, rivers, or surrounding land [15]. When discharged into water bodies it turns the water brown, smelly, and slimy and causes anoxygenation [16], and may kill fishes and other aquatic organisms thereby denying humans access to good water for domestic use [17]. Also, application of untreated POME on soil alters its physic-chemical properties, causing undesirable decreases in $\mathrm{pH}$ and increases in salinity. Unfortunately, most oil palm processors still discharge raw effluent directly into nearby streams and rivers and on land [18].

Several treatment technologies have been applied to POME with varying levels of success. These include ponding [19], aerobic digestion [20], anaerobic digestion [21], and physicochemical treatments $[22,23]$. These methods seek to dispose of POME without any consideration to the current trend in the management of high strength agro-food wastes that seeks to reprocess them through value addition [24]. The management of agro-food wastes has evolved from treatment for disposal to beneficial utilization of resources through valorization [24-26]. Valorization is a concept that seeks the recovery of value added products from wastes and effluents through the application of cost effective technologies. Since POME has currently little or no recycling value, it constitutes an environmental hazard, undergoing slow (acidic) degradation in pits from which it emits strong, foul odour causing air pollution and contamination of ground and surface waters and agricultural land besides vector attraction. Attempts have been made to achieve valorization of POME through production of microbial biomass, enzymes, energy, and biochemicals [27-38].

Cost effective disposal of POME hinges on a sustainable and economic method for treatment. Where this can be coupled to some value addition it will become an incentive resulting in a no-loss waste treatment, or a reduction in the overall cost, with the achievement of clean environment being a bonus. The possibility of using POME for biomass production has been suggested and, in this regard, room for innovation exists in both the choice of microbe and fermentation environment. It is envisaged that development of a process for production of yeast biomass from POME will reduce the time and cost in the cycle-to-value and thereby create opportunities for the valorization of a waste stream the accumulation and environmental concern for which can only increase with increasing global production of palm oil. This work was carried out to study the treatment and valorization of POME through production of yeast biomass and to assess the quality of the biomass in terms of amino acid content.

\section{Materials and Methods}

2.1. Collection of POME. Raw POME was obtained from a local palm oil processor employing manual process in Ejuona Obukpa Community in Nsukka Local Government Area of Enugu State, Nigeria. Samples were collected in clean containers and transported to the laboratory. The fresh
POME was dispensed in $500 \mathrm{~mL}$ containers and stored frozen in a deep freezer when not used immediately.

\subsection{Isolation and Identification of POME Utilising Yeasts.} Yeasts were isolated from stale POME and soil taken from POME dump site and from palm wine (all collected from the same community as above). Stale POME, soil, and palm wine samples were collected in sterile sample bottles and taken immediately to the laboratory for analysis. Samples were processed by 1:10 serial dilution in sterile half strength peptone water and plated by pour plate method on Saboraud Dextrose Agar (SDA) medium (Oxoid, England) supplemented with chloramphenicol $\left(50 \mu \mathrm{gmL}^{-1}\right.$ final concentration). Plates were incubated at room temperature $\left(30^{\circ} \mathrm{C} \pm 2^{\circ} \mathrm{C}\right)$ for up to 72 hours or until yeast colonies appeared if earlier. Yeast colonies that appeared on the media were purified on fresh plates of SDA. Pure colonies of representative isolates were stored on slants of SDA at $4^{\circ} \mathrm{C}$ until needed.

2.2.1. Identification of Yeast Isolates. All the yeasts isolates were identified using conventional microbiological methods based on their cultural, morphological, and physiological/biochemical characteristics as described by Kurtzman and Fell [39]. Isolates were also tested for their ability to growth at $37^{\circ} \mathrm{C}$ and $40^{\circ} \mathrm{C}$. Microscopy was carried out with a drop of lacto-phenol cotton blue stain at $\times 40$ objective.

2.2.2. Carbon Fermentation Test. Each isolate was tested for ability to ferment different sugars with the production of acid and or gas. Fermentation basal medium containing bromothymol blue indicator was prepared with $2 \%$ sugars (except for raffinose which was used at 4\%). Basal medium was prepared by dissolving $4.5 \mathrm{~g}$ of powdered yeast extract, $7.5 \mathrm{~g}$ of peptone, and $26.7 \mathrm{mg}$ of bromothymol blue indicator in 1 litre of distilled water. A $6 \mathrm{~mL}$ volume of the medium was dispensed in fermentation tube containing inverted Durham tube for detection of gas production. The tubes were capped and sterilized at $121^{\circ} \mathrm{C}$ for 10 minutes. Suspensions of the isolated yeast cells were made from $24 \mathrm{~h}$ cultures of isolates using sterile distilled water. Each tube containing the test medium was inoculated with $0.1 \mathrm{~mL}$ of the yeast suspension $\left(5 \times 10^{6} \mathrm{~mL}^{-1}\right)$ and incubated at $25^{\circ} \mathrm{C}$ for two weeks. The tubes were shaken and inspected at frequent intervals for accumulation of gas in the Durham tube and change of colour of indicator. A positive result was indicated by a colour change from deep green to yellow for acid production and accumulation of air in the Durham tube for gas production. The results were scored according to the scheme of Kurtzman and Fell [39].

2.2.3. Carbon Assimilation Test. Each isolate was tested for ability to assimilate different sugars using Yeast Nitrogen Base (YNB) agar slants containing 2\% sugar (except for raffinose which was $4 \%$ ). The media were prepared as described by Kurtzman and Fell [39]. Slant of the test medium was inoculated with $0.1 \mathrm{~mL}$ suspension of test isolate. The tests were incubated at $25^{\circ} \mathrm{C}$ in a cool incubator and inspected after 1,2 , and 3 weeks. A positive result is indicated by the growth of 
the yeasts after some days and heavy growth signifies strong assimilation [39].

2.2.4. Nitrogen Assimilation Test. This test was carried out as for carbon assimilation test but using Yeast Carbon Base (YCB) agar containing different nitrogen sources. Each isolate was tested for ability to utilize different nitrogen compounds as sole source of nitrogen. The two nitrogen sources used were potassium nitrate (test nitrogen source) and ammonium sulphate (positive control). YCB was prepared as described by Kurtzman and Fell [39] and inoculated as above. The tests were incubated at $25^{\circ} \mathrm{C}$ in a cool incubator and inspected for growth after 1, 2, and 3 weeks. A positive result is indicated by the growth of the yeasts after some days and heavy growth signifies strong assimilation.

2.2.5. Growth at Different Temperatures. This test was carried out using glucose-peptone-yeast extract (GPYE) broth. The broth was prepared by dissolving $20 \mathrm{~g}$ of glucose, $10 \mathrm{~g}$ of peptone, and $5 \mathrm{~g}$ of yeast extract in 1 litre of distilled water. A $6 \mathrm{~mL}$ volume of this medium was dispensed in test tubes, plugged with cotton wool, and sterilized at $121^{\circ} \mathrm{C}$ for 15 minutes. Each of the tubes was inoculated with $0.1 \mathrm{~mL}$ of test yeast suspension incubated at $25^{\circ} \mathrm{C}, 30^{\circ} \mathrm{C}, 37^{\circ} \mathrm{C}$, and $40^{\circ} \mathrm{C}$ for one week. The tubes were inspected each day for growth.

2.3. Preparation of Yeast Inoculum for Growth in POME. Inoculum was prepared by adding $5 \mathrm{~mL}$ of sterile $0.85 \%$ normal saline onto 2-day-old SDA slant cultures in universal bottles and gently rubbing with sterile wire loop to dislodge yeast growth. The yeast concentration was adjusted to approximately $5.0 \times 10^{6}$ cells $\mathrm{mL}^{-1}$ using a haemocytometer and fresh inoculum was prepared from 24 hour culture for each parameter [40]. Prior to fermentation, POME was allowed to completely thaw at room temperature, boiled, and filtered while still hot by simple surface filtration using a double layered muslin cloth to remove coarse solids followed by fine filtration through Whatman Number 41 filter paper.

2.4. Determination of Physicochemical Parameters of POME. The total solids (TS) and total suspended solids (TSS) were determined as described in standard methods [41]. The chemical oxygen demand (COD) was determined by using modified titrimetric/dichromate oxidation method [41]. The total dissolved solid (TDS) was determined using Hanna portable TDS metre. Total ash was determined by ignition of the total solids in a muffle furnace at $550^{\circ} \mathrm{C}$ (Gallenkamp, size 3, England). Total lipid was determined by extraction with chloroform/methanol $(2: 1)$, according to the method of Folch et al. [42]. Total nitrogen was determined using Kjeldahl method [43]. The $\mathrm{pH}$ of POME as well as change in $\mathrm{pH}$ of the fermenting medium was measured using Hanna portable $\mathrm{pH}$ meter (HANNA HI 198107, USA). The organic carbon was determined by dichromate oxidation method [44].

2.5. Screening of Isolates for Biomass Production and COD Reduction. Isolates were screened to determine their ability to degrade $\mathrm{COD}$ of POME and to produce biomass under culture conditions. Erlenmeyer flasks of $250 \mathrm{~mL}$ capacity containing $25 \mathrm{~mL}$ of POME were set up in duplicates and sterilized at $121^{\circ} \mathrm{C}$ for $15 \mathrm{~min}$. When cooled, each flask was inoculated with $1 \mathrm{~mL}$ suspension of the test isolates and incubated at $28 \pm 2^{\circ} \mathrm{C}$ on a rotary shaker incubator (model KS 4000 I Control (IKA-Werke GmbH Germany)) at $150 \mathrm{rpm}$ for 7 days. Sterile POME medium was included as control. Changes in the COD and physicochemical parameters of POME were monitored throughout the fermentation period as above.

At the end of culture the biomass was harvested by centrifuging the culture medium at $5000 \times \mathrm{g}$ for 20 minutes, using Hettich II centrifuge. The pellets were washed several times with cold distilled water and then dried in an oven at $80^{\circ} \mathrm{C}$, using preweighed filter paper to constant weight (Sartorius model AGBS 323S Sartorius, AG Germany). This was followed by the filtration of the supernatant through a preweighed membrane filter of $0.45 \mu \mathrm{m}$ pore size. The filters were washed with distilled water severally and then dried at $80^{\circ} \mathrm{C}$ for at least $16 \mathrm{~h}$ to constant weight. The biomass concentration was estimated from the membrane and filter paper weight difference with and without the dried sample. The determinations were performed in duplicate. The supernatant was used for determination of residual COD.

2.6. Amino Acid Analysis of Yeast Biomass. Amino acid analysis was done in accordance with the Technical method of AOAC [41]. Exactly $1 \mathrm{~g}$ of the dried yeast biomass was placed in the conventional hydrolysis tubes. To each tube $100 \mu \mathrm{L}$ of $6 \mathrm{molL}^{-1} \mathrm{HCl}$ containing $30 \mathrm{~mL}$ phenol and $10 \mathrm{~mL}$ 2-mercaptoethanol ( $\left.6 \mathrm{molL}^{-1} \mathrm{HPME}\right)$ were added and the tubes were evacuated, sealed, and hydrolyzed at $110^{\circ} \mathrm{C}$ for 22 hours. After hydrolysis, $\mathrm{HCl}$ was evaporated in a vacuum bottle heated to $60^{\circ} \mathrm{C}$. The residues were dissolved in ultrapure water (HPLC) grade, containing ethylene diamine tetra acetic acid (EDTA). The hydrolyzed samples were derivatised (45 minutes per sample) on Waters 616/626 HPLC by reacting free amino acids, under basic condition, with phenylisothiocyanate (PITC) to obtain phenyl-thiocarbamyl (PTC) amino acid derivatives and analyzed by using reverse phase HPLC (Waters 616/626 LC USA). A set of standard solutions of the amino acids were prepared from Pierce Reference standards $\mathrm{H}(1000 \mu \mathrm{mol})$ into autosampler crops and also derivatised. These standards $(0.0,0.5,1.0,1.5,2.0 \mu \mathrm{mol})$ were used to generate a calibration file that was used to determine the amino acid contents of the samples. After the derivatisation methanol solution $(1.5 \mathrm{~N})$ containing the PTCamino acids were transferred to a narrow bore waters $616 / 626$ HPLC system for separation.

The separation and quantization of the PTC-amino acids were done on a reverse phase 18 silica column and the PTC chromophores were detected at $254 \mathrm{~nm}$. The column temperature was $60^{\circ} \mathrm{C}$ and elution took 30 minutes. The buffer system used for separation was $140 \mathrm{~mm}$ sodium acetate pH 5.50 as buffer A and $80 \%$ acetonitrile as buffer B. The program was run using a gradient of buffer $A$ and buffer $B$ concentration and ended with a $55 \%$ buffer B concentration at the end of the gradient. The chromatographic peaks areas 
TABLE 1: Morphological and microscopic characteristics of the isolated yeasts.

\begin{tabular}{lccccccc}
\hline Characteristics & $\mathrm{L}_{3}{ }^{1}$ & $\mathrm{SP}^{5}$ & TMCC & TWC & TWDC & $\mathrm{V}_{4}{ }^{2}$ & $\mathrm{~V}_{4}{ }^{5}$ \\
\hline Colour on SDA & Creamy white & Tannish white & Glistening Cream & Cream & White & Creamy white & Cream \\
Colour on Chromagar & Purple & Pale pink & White & Blue & Dark blue & Purple & Pale pink \\
Colony surface & Smooth & Smooth & Smooth & Smooth & Smooth & Smooth & Smooth \\
Texture & Butyrous & Butyrous & Butyrous & Butyrous & Butyrous & Butyrous & Butyrous \\
Margin & Irregular & Irregular & Entire & Irregular & Irregular & Circular & Irregular \\
Elevation & Sl. raised & Raised & Raised & Raised & Raised & Sl. Raised & Flat \\
Cell shape & Spherical & Ellipsoidal & Globose & Ellipsoidal & Spherical & Globose & Spherical \\
Ascospore & $\mathrm{P}$ & $\mathrm{P}$ & $\mathrm{P}$ & $\mathrm{P}$ & $\mathrm{P}$ & $\mathrm{P}$ & $\mathrm{P}$ \\
Pseudomycelium & $\mathrm{P}$ & $\mathrm{P}$ & $\mathrm{A}$ & $\mathrm{P}$ & $\mathrm{P}$ & $\mathrm{P}$ & $\mathrm{P}$ \\
True mycelium & $\mathrm{A}$ & $\mathrm{A}$ & $\mathrm{A}$ & $\mathrm{A}$ & $\mathrm{P}$ & $\mathrm{A}$ & $\mathrm{A}$ \\
Blastoconidia & $\mathrm{P}$ & $\mathrm{P}$ & $\mathrm{P}$ & $\mathrm{P}$ & $\mathrm{A}$ & $\mathrm{P}$ & $\mathrm{A}$ \\
Pellicle & $\mathrm{A}$ & $\mathrm{P}$ & $\mathrm{A}$ & $\mathrm{P}$ \\
\hline
\end{tabular}

Key: $\mathrm{P}$ = present; $\mathrm{A}$ = absent; sl. = slightly.

TABLE 2: Physiological characteristics of the isolated yeasts.

\begin{tabular}{|c|c|c|c|c|c|c|c|}
\hline Physiological test & $\mathrm{L}_{3}{ }^{1}$ & $\mathrm{SP}^{5}$ & TMCC & TWC & TWDC & $\mathrm{V}_{4}^{2}$ & $\mathrm{~V}_{4}{ }^{5}$ \\
\hline Glucose & FA & FA & SA & FA & FA & FA & FA \\
\hline Galactose & FA & FA & SA & SA & FA & FA & FA \\
\hline Sucrose & FA & FA & SA & FA & FA & FA & FA \\
\hline Raffinose & FA & WA & SA & FA & - & FA & FA \\
\hline Maltose & $-\mathrm{A}$ & $-\mathrm{A}$ & $-\mathrm{A}$ & - & FA & - & $-\mathrm{A}$ \\
\hline Lactose & - & - & - & - & - & - & - \\
\hline Soluble starch & - & - & - & - & $-\mathrm{A}$ & - & - \\
\hline Xylose & - & $-\mathrm{A}$ & - & $S$ & $-\mathrm{A}$ & - & $-\mathrm{A}$ \\
\hline Nitrate & - & + & + & - & - & - & - \\
\hline Growth at $25^{\circ} \mathrm{C}$ & + & + & + & + & + & + & + \\
\hline Growth at $30^{\circ} \mathrm{C}$ & + & + & + & + & + & + & + \\
\hline Growth at $37^{\circ} \mathrm{C}$ & + & - & + & + & + & + & + \\
\hline Growth at $40^{\circ} \mathrm{C}$ & + & + & + & + & + & + & + \\
\hline Probable identity & Saccharomyces sp & Pichia sp & Candida sp & Candida sp & Candida sp & Saccharomyces sp & Pichia \\
\hline
\end{tabular}

Key: $\mathrm{FA}=$ fermentation and gas production; $-\mathrm{A}=$ assimilation only; $+=$ positive; $-=$ negative.

were identified and quantified using a Dionex chromeleon data analysis system attached to the HPLC System. The calibration curve or file prepared from the average values of the retention times (minutes) and areas (in $\mathrm{Au}$ ) of the amino acids in 5 standard runs was used. Amino acid was expressed as $\mathrm{g} 100 \mathrm{~g}^{-1}$ of proteins and compared with FAO/WHO [45] reference.

2.7. Statistical Analysis of the Experimental Data. All results were expressed based on duplicate determinations. Data collected were subjected to analysis of variance (ANOVA) using GenStat discovery edition 4 and means were compared using least significant difference at $95 \%$ confidence and separated using Duncan new Multiple Range Test.

\section{Results}

3.1. Identification of POME Utilizing and Associated Yeasts. Seven representative isolates of POME utilizing yeasts were selected from a total of more than 100 initial isolates based on the amount of biomass accumulated and identified. Two of the representative isolates identified as Candida sp TMCC and Pichia sp $\mathrm{SP}^{5}$ were obtained from POME dump site, another two identified as Candida spp. TWDC and TWC were from stale POME, while the remaining three isolates identified as Saccharomyces spp $\mathrm{L}_{3}{ }^{1}$ and $\mathrm{V}_{4}{ }^{2}$ and Pichia sp $\mathrm{V}_{4}{ }^{5}$ were from palm wine. Table 1 shows the morphological characteristics of the isolates yeasts, while Table 2 shows their physiological characteristics.

3.2. Physicochemical Parameters of POME. The proximate characteristics of the raw POME used in this study are presented in Table 3. The POME contained high amount of total solids $\left(76,000 \mathrm{mgL}^{-1}\right)$, total suspended solids $(44,000$ $\left.\mathrm{mgL}^{-1}\right)$, total dissolved solids $\left(32,000 \mathrm{mgL}^{-1}\right)$, organic carbon $\left(15128 \mathrm{mgL}^{-1}\right)$, lipid $\left(3,580 \mathrm{mgL}^{-1}\right)$ ash $\left(4,000 \mathrm{mgL}^{-1}\right)$, and COD $\left(114,800 \mathrm{mgL}^{-1}\right)$ but a low amount of total nitrogen (420 $\mathrm{mgL}^{-1}$ ) and had an acidic $\mathrm{pH}$ (3.9). On the bases of these, the $\mathrm{C}: \mathrm{N}$ ratio of $36: 1$ was calculated. 
TAble 3: Proximate composition of raw POME ( $\mathrm{pH}$ 3.9).

\begin{tabular}{lc}
\hline Parameter & Concentration $(\mathrm{mg} / \mathrm{L})$ \\
\hline COD & 114,800 \\
Total solid & 76,000 \\
Total dissolved solid & 32,000 \\
Total suspended solid & 44,000 \\
Total lipid & 3,580 \\
Total nitrogen & 420 \\
Ash & 4,000 \\
Total organic carbon & 87,140 \\
\hline
\end{tabular}

3.3. Biomass Accumulation and COD Degradation by Isolates. As shown in Figure 1, the isolates differed from one another in their ability to reduce COD content of POME in the course of fermentation for biomass production and reduction in pollution potential. The isolates achieved peak reduction of POME COD content after 72, 96, 120, or 144 hours. Isolate $\mathrm{L}_{3}{ }^{1}$ achieved the highest reduction in COD $(83 \%$ reduction after 96 hours), while $\mathrm{SP}^{5}$ achieved the least COD reduction (73\% reduction after 72 hours). During the fermentation, there was a rise in $\mathrm{pH}$ of the POME medium for all the isolates from the initial acid value to alkaline levels (Figure 2). The yield of biomass by the isolates is shown in Figure 3 . Biomass accumulation mirrored the trend of COD removal and increased with duration of fermentation to a peak point corresponding to time of maximum COD removal after which it decreased. A slight exception was in the case of isolate TWDC, which showed increase in biomass production throughout the fermentation. Isolate $\mathrm{L}_{3}{ }^{1}$ showed increase in biomass production up to 96 hours when a maximum of $4.42 \mathrm{gL}^{-1}$ (the highest in the process) was obtained after which it declined while isolate $\mathrm{SP}^{5}$ achieved maximum production of $3.14 \mathrm{gL}^{-1}$ at the 72 hours. Isolates TMCC and TWC yielded their maximum biomass of $1.94 \mathrm{gL}^{-1}$ (the least in the process) and $2.22 \mathrm{gL}^{-1}$, respectively, after 120 hours, while TWDC gave maximum biomass yield of $3.06 \mathrm{gL}^{-1}$ at 168 hour. Isolate $\mathrm{V}_{4}^{2}$ gave maximum biomass yield of $3.02 \mathrm{gL}^{-1}$ after 72 hours, while isolate $\mathrm{V}_{4}{ }^{5}$ yielded its maximum biomass of $3.46 \mathrm{gL}^{-1}$ after 144 hours.

\subsection{Proximate Composition and Amino Acid Profile of Micro-} bial Biomass. Following the biomass yield screen, isolate $\mathrm{L}_{3}{ }^{1}$ was selected for production of biomass for proximate and amino acid analysis. This isolate was selected for biomass production and amino acid analysis because it produced the most biomass of all the isolates and was also very effective in the reduction of waste pollution potential (COD). The biomass produced in POME had a moisture content of $8.95 \%$ and a dry matter content of $91.05 \%$. The biomass crude protein content was approximately $27 \%$ while the fat, carbohydrate, crude fibre, and ash contents were $0.83 \%$, $35.45 \%, 4.70 \%$, and $6.12 \%$, respectively, for biomass harvested at peak biomass content (96 hours culture). Table 4 shows the amino acid profile of the biomass protein. A comparison of the amino acid composition of the biomass with FAO standard for SCP protein intended for use in animal feeding indicates that the biomass was comparable to or superior to the recommended standard with respect to a number of amino acids, while being inferior with respect to only a few others.

\section{Discussion}

In this study, seven yeasts isolated from palm wine $\left(\mathrm{L}_{3}{ }^{1}, \mathrm{~V}_{4}{ }^{2}\right.$ and $\mathrm{V}_{4}{ }^{2}$ ), stale POME (TWDC and TWC), and POME dump site (TMCC and $\mathrm{SP}^{5}$ ) were screened for their efficiency in reducing the COD content (pollution potential) of POME while producing biomass. Based on their colonial and physiological characteristics [39], the isolates were identified as species of Saccharomyces $\left(\mathrm{L}_{3}{ }^{1}\right.$ and $\left.\mathrm{V}_{4}{ }^{2}\right)$, Pichia $\left(\mathrm{V}_{4}{ }^{5}\right.$ and $\left.\mathrm{SP}^{5}\right)$, and Candida (TMCC, TWC, and TWDC).

The proximate composition of POME used in this study indicates high total solid but was considerably different from those used in some previous studies [7, 11-13]. This is probably due to differences in the nature of the mill and process operation. The POME used in this study was obtained from local palm oil extractors who use manual method of oil extraction. This method is inefficient in recapturing all the oil in the palm fruits. The manual method employs smaller volume of water (relative to the mechanized process) to achieve oil extraction and allows for a considerable reduction in the volume of wastewater generated in the process. However, the reduction in effluent volume results in a more concentrated effluent with higher content of organic matter. The use of limited volume of water for oil extraction particularly in the upland area of this study is understandable since water is not available in unlimited quantities outside the wet season. It is also possible that the fruits may have undergone some deterioration prior to processing thereby increasing the polluting potential of the effluent. Delay in processing of produce results in degradation of oil/lipids into low molecular weight organic acids that remains in solution and so are not extracted with oil. This leads to low $\mathrm{pH}$ and high content of soluble solids and pollution potential of the ensuring POME, and is common during the fruit season when many manual small holder processors are regularly overwhelmed.

The POME used in this study had a $\mathrm{pH}$ of 3.9. This value falls in the range of 3.5 to 5.0 reported by other authors [46-48]. It is however lower than the guideline value ( $\mathrm{pH} \mathrm{6-9)}$ for effluent from vegetable oil processing [49]. The total lipid content $\left(3580 \mathrm{mgL}^{-1}\right)$ was comparable to but lower than the range of $4000-6000 \mathrm{mgL}^{-1}$ reported by $\mathrm{Ma}[14]$ and much higher than the regulatory discharge limit of oil and grease in POME $\left(50 \mathrm{mgL}^{-1}\right.$ [7]), a value that is low and considerably challenging to achieve in most POME management procedures. COD values reported for POME vary considerably from less than $42,000 \mathrm{mgL}^{-1}$ to over $112,000 \mathrm{mgL}^{-1}[7,11-13]$. The value of COD $\left(114,800 \mathrm{mgL}^{-1}\right)$ recorded in this study was high but compares closely to figures that have been reported. It is, however, several orders of magnitude higher than the IFC [49] guideline value of $250 \mathrm{mgL}^{-1}$ for effluent from vegetable oil processing and so requires significant treatment prior to disposal. It is also 


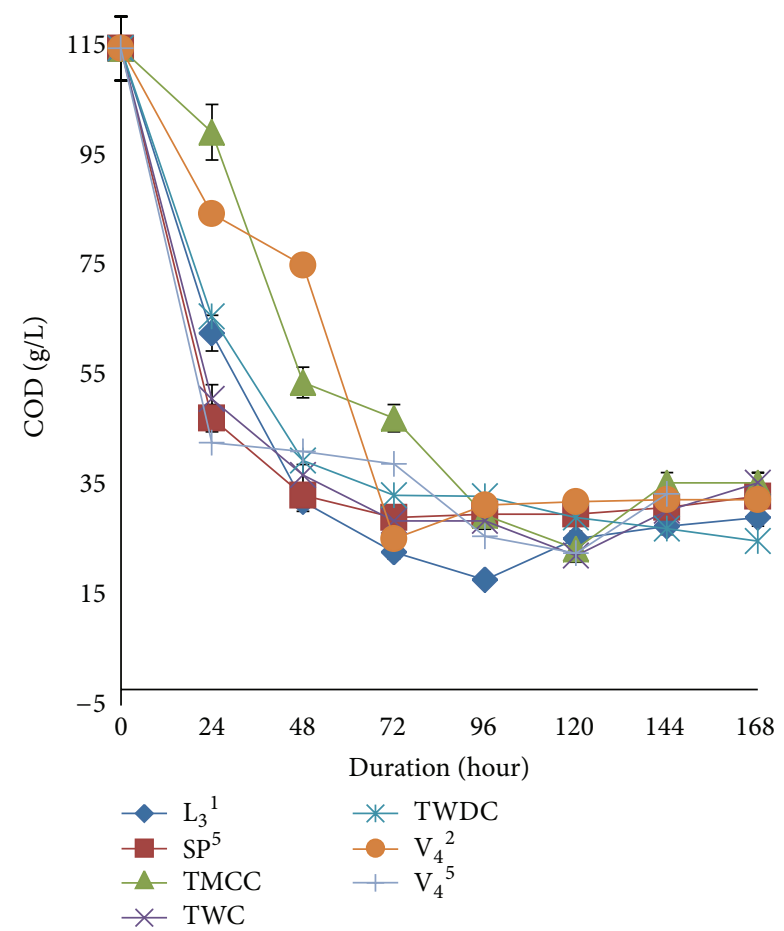

FIgure 1: Changes in COD of POME with fermentation time.

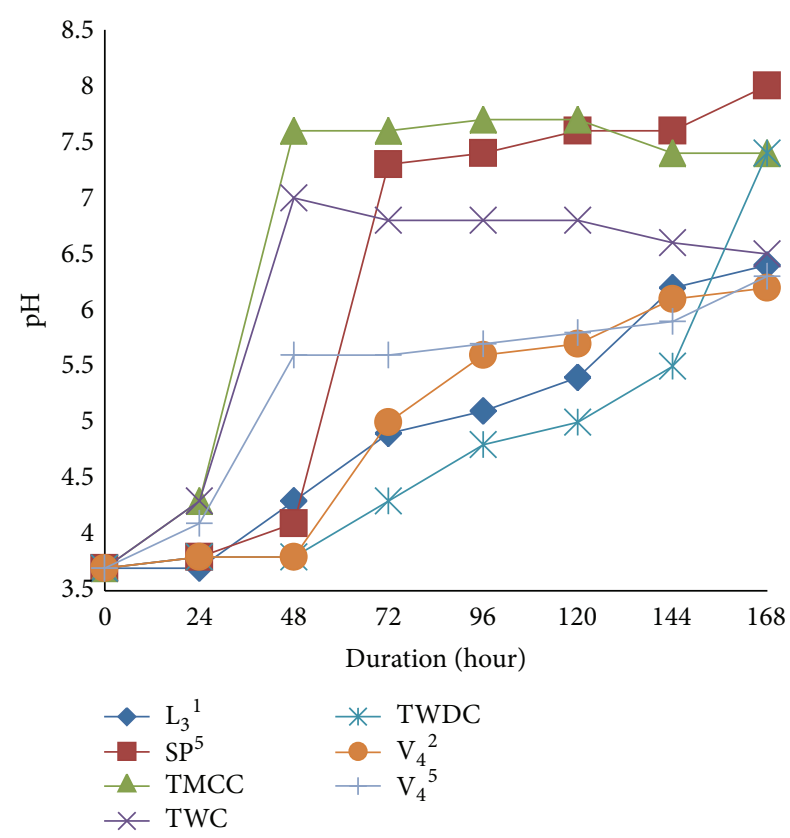

FIGURE 2: Changes in $\mathrm{pH}$ of POME with fermentation time.

consistent with the high values of TS obtained and may be the result of incomplete extraction of lipid as has been reported by Oswal et al. [50].

The yeast isolates obtained in this study varied considerably in their ability to grow in POME and accumulate biomass. They also showed variations in their ability to reduce the COD load of the POME. Of the seven isolates

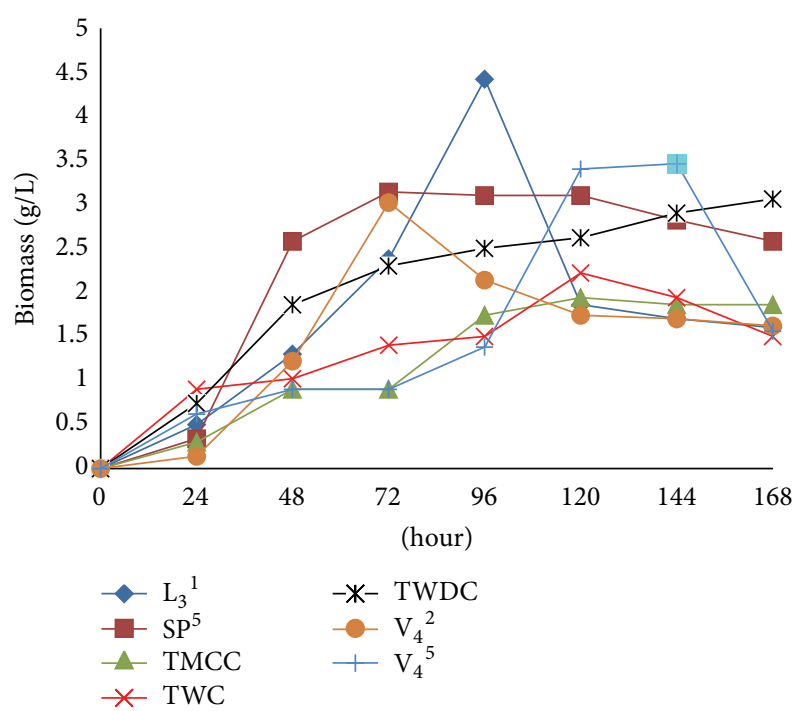

FIGURE 3: Biomass yield of the different isolates in POME.

screened, Saccharomyces sp $\mathrm{L}_{3}{ }^{1}$ showed the highest COD reduction of $83 \%$ in $96 \mathrm{~h}$. This is comparable to the COD reduction value (82\%) reported by Alam et al. [51] when Aspergillus niger (A103) was used to produce citric acid in POME. If the reduction of COD were the sole end of the process then the used Saccharomyces $\mathrm{sp}_{3}{ }^{1}$ will be considered more economical, even though the product of this process retained higher $\mathrm{COD}$ than the regulatory requirement for final disposal. Barker and Worgan [52] reported 77\% COD reduction in POME used for mycoprotein production after 2 days, while Oswal et al. [50] obtained higher COD reduction (96\%) in culture of Yarrowia lipolytica NCIM 3589. Using Rhodotorula glutinis Saenge et al. [53] on the other hand obtained only $66 \%$ COD removal in POME during lipid and carotenoid production. Our process also compares with but is slightly better in COD reduction than $80 \%$ reported during anaerobic digestion of POME [21]. Growth of Saccharomyces $\mathrm{sp}_{3}{ }^{1}$ in POME was accompanied by a rise in $\mathrm{pH}$ to 8.0. This is consistent with the report of $\mathrm{Wu}$ et al. [35], who explained the rise due to utilization of organic acid and would make adjustment of $\mathrm{pH}$ during mass propagation of yeasts in this medium unnecessary.

The peak biomass accumulation of $4.42 \mathrm{gL}^{-1}$ obtained by Saccharomyces $\mathrm{L}_{3}{ }^{1}$ shows the isolate as the best for biomass production in POME (Figure 1). This result is consistent with data reported by Nwuche et al. [54], who obtained maximum biomass of $4.0 \mathrm{gL}^{-1}$ when A. niger ATCC 9642 was cultured in POME. Saenge et al. [53] on the other hand, obtained $7.5 \mathrm{gL}^{-1}$ biomass when the oleaginous Rhodotorula glutinis TISTR was used to produce biomass, lipid, and carotenoid in POME. The total protein content of Saccharomyces $\mathrm{L}_{3}{ }^{1}$ at peak biomass production was $27 \%$ while the fat, carbohydrate, crude fibre, and ash contents were $0.83 \%, 35.45 \%, 4.70 \%$, and $6.12 \%$ of dry biomass, respectively, making the resulting biomass quite suitable for feed use.

A comparison of the amino acid composition of the biomass with FAO standard for SCP protein intended for 
TABLE 4: Amino acid profile of isolate $\mathrm{L}_{3}{ }^{1}$ cultured in POME in $\mathrm{g} / 100 \mathrm{~g}$ of protein.

\begin{tabular}{lcc}
\hline Amino acids & $\begin{array}{c}\text { Amino acid content } \\
\text { g/100 g protein }\end{array}$ & $\begin{array}{c}\text { FAO/WHO } \\
\text { Standard }\end{array}$ \\
\hline${ }^{*}$ Phe + Tyr & 8.68 & 6.3 \\
Isoleucine & 3.09 & 2.8 \\
Leucine & 10.25 & 6.6 \\
Lysine & 6.01 & 5.8 \\
Methionine & 5.05 & 2.5 \\
Tryptophan & 6.76 & 1.1 \\
Valine & 7.13 & 3.5 \\
Threonine & 3.57 & 3.4 \\
Histidine & 1.91 & 1.9 \\
Total essential & 52.45 & 33.9 \\
Proline & 1.87 & 10.7 \\
Alanine & 2.97 & 6.1 \\
Glutamine & 2.95 & \\
Glutamic acid & 11.1 & 14.7 \\
Glycine & 3.71 & 2.2 \\
Serine & 3.57 & 7.7 \\
Arginine & 3.85 & 5.2 \\
Aspartic acid & 2.60 & 7.7 \\
Asparagine & 8.54 & \\
Trimethylserine & 3.53 & 54.3 \\
Total nonessential & 34.70 & \\
Total amino acids & 87.15 & \\
\hline & & \\
\hline
\end{tabular}

FAO/WHO (1991) [45].

${ }^{*}$ Phe and Tyr were taken together.

use in animal feeding (Table 4) indicates that the biomass was comparable to or superior to the recommended standard with respect to a number of amino acids, while being inferior with respect to only a few others, mostly nonessential amino acids. The amino acid profile of this isolate shows that it is also superior to the that of thermophilic Bacillus stearothermophilus isolated from thermophilic digestion of agricultural residue [24]. The superior content of essential amino acid in this biomass relative to FAO standards for feed is interesting considering the status of the substrate as waste and the possibility of using this process to produce valuable biomass while achieving economic waste disposal. As culture conditions affect the amino acid profiles of microbial biomass [24] these may be manipulated in optimization processes to improve the content of desired amino acids. It is remarkable that biomass produced in this waste is nutritionally qualitative. In many rural Nigeria villages stale POME with visible yeast and fungal growth is usually traditionally fed to swine either directly or used in compounding feed.

\section{Conclusion}

This work has shown that POME can be used to produce yeast biomass by fermentation without costly pretreatment or nutrient supplementation. The biomass production process worked as a cost effective biological treatment for the reduction of pollution in the industrial wastewater, requiring simple and feasible methods that can be operated in the industry, so minimizing by products. In small scale process the cultured POME may also be fed as enriched feed directly to animals or used in compounding feed. This will remove the cost that may be associated with harvest of biomass.

\section{Conflict of Interests}

The authors declare that there is no conflict of interests regarding the publication of this paper.

\section{References}

[1] United Stated Department of Agriculture Foreign Agricultural Service, "Oil Seeds: World Markets and Trade," 2011, http://www.fas.usda.gov/.

[2] E. I. Ohimain, A. A. Oyedeji, and S. C. Izah, "Employment effects of smallholder oil palm processing plants in Elele, Rivers State, Nigeria," International Journal of Applied Research and Technology, vol. 1, no. 6, pp. 83-93, 2012.

[3] E. I. Ohimain, C. Daokoru-Olukole, S. C. Izah, and E. E. Alaka, "Assessment of the quality of crude palm oil produced by smallholder processors in Rivers State, Nigeria," Nigerian Journal of Agriculture, Food and Environment, vol. 8, pp. 28-34, 2012.

[4] IndexMundi, Index Palm Oil Production by Country in 1000 MT, 2013, http://www.indexmundi.com/agriculture/?commodity $=$ palm-oil\&graph=production.

[5] V. O. Nwaugo, G. C. Chinyere, and C. U. Inyang, "Effects of palm oil mill effluents (POME) on soil bacterial flora and enzyme activities in Egbama," Plant Product Research Journal, vol. 12, pp. 10-13, 2008.

[6] O. Chavalparit, W. H. Rulkens, A. P. J. Mol, and S. Khaodhair, "Options for environmental sustainability of the crude palm oil industry in Thailand through enhancement of industrial ecosystems," Environment, Development and Sustainability, vol. 8, no. 2, pp. 271-287, 2006.

[7] A. L. Ahmad, S. Ismail, and S. Bhatia, "Water recycling from palm oil mill effluent (POME) using membrane technology," Desalination, vol. 157, no. 1-3, pp. 87-95, 2003.

[8] E. I. Ohimain and S. C. Izah, "Water minimization and optimization by small-scale palm oil mill in Niger Delta, Nigeria," Journal of Water Research, vol. 135, pp. 190-198, 2013.

[9] O. I. Osemwota, "Effect of abattoir effluent on the physical and chemical properties of soils," Environmental Monitoring and Assessment, vol. 167, no. 1-4, pp. 399-404, 2010.

[10] Y. S. Madakil and L. Seng, "Pollution control: how feasible is zero discharge concepts in Malaysia palm oil mills," American Journal of Engineering Research, vol. 2, pp. 239-252, 2013.

[11] S. O-Thong, C. Mamimin, and P. Prasertsan, "Effect of temperature and initial $\mathrm{pH}$ on biohydrogen production from palm oil mill effluent: Long-term evaluation and microbial community analysis," Electronic Journal of Biotechnology, vol. 14, no. 5, 2011.

[12] W. Choorit and P. Wisarnwan, "Effect of temperature on the anaerobic digestion of palm oil mill effluent," Electronic Journal of Biotechnology, vol. 10, no. 3, pp. 376-385, 2007.

[13] G. D. Najafpour, A. A. L. Zinatizadeh, A. R. Mohamed, M. Hasnain Isa, and H. Nasrollahzadeh, "High-rate anaerobic digestion of palm oil mill effluent in an upflow anaerobic sludgefixed film bioreactor," Process Biochemistry, vol. 41, no. 2, pp. 370-379, 2006. 
[14] A. N. Ma, "Environmental management for the oil palm industry," Palm Oil Development, vol. 30, pp. 1-10, 2000.

[15] O. L. Okwute and N. R. Isu, "Impact analysis of palm oil mill effluent on the aerobic bacterial density and ammonium oxidizers in a dumpsite in Anyigba, Kogi State," African Journal of Biotechnology, vol. 6, no. 2, pp. 116-119, 2007.

[16] O. O. Awotoye, A. C. Dada, and G. A. O. Arawomo, "Impact of palm oil processing effluent discharge on the quality of receiving soil and river in south western Nigeria," Journal of Applied Sciences Research, vol. 7, no. 2, pp. 111-118, 2011.

[17] L. I. N. Ezemonye, D. F. Ogeleka, and F. E. Okieimen, "Lethal toxicity of industrial chemicals to early life stages of Tilapia guineensis," Journal of Hazardous Materials, vol. 157, no. 1, pp. 64-68, 2008.

[18] J. C. Igwe, C. O. Onyegbado, and A. A. Abia, "Studies on the kinetics and intraparticle diffusivities of BOD, colour and TSS reduction from palm oil mill effluent (POME) using boiler fly ash," African Journal of Environmental Sciences and Technology, vol. 4, no. 6, pp. 392-400, 2010.

[19] K. K. Chin, S. W. Lee, and H. H. Mohammad, "A study of palm oil mill effluent treatment using a pond system," Water Science and Technology, vol. 34, no. 11, pp. 119-123, 1996.

[20] M. I. A. Karim and A. Q. A. Kamil, "Biological treatment of palm oil mill effluent using Trichoderma viride," Biological Wastes, vol. 27, no. 2, pp. 143-152, 1989.

[21] S. Yacob, M. A. Hassan, Y. Shirai, M. Wakisaka, and S. Subash, "Baseline study of methane emission from open digesting tanks of palm oil mill effluent treatment," Chemosphere, vol. 59, no. 11, pp. 1575-1581, 2005.

[22] A. L. Ahmad, S. Bhatia, N. Ibrahim, and S. Sumathi, "Adsorption of residual oil from palm oil mill effluent using rubber powder," Brazilian Journal of Chemical Engineering, vol. 22, no. 3, pp. 371379, 2005.

[23] A. L. Ahmad, M. F. Chong, S. Bhatia, and S. Ismail, "Drinking water reclamation from palm oil mill effluent (POME) using membrane technology," Desalination, vol. 191, no. 1-3, pp. 3544, 2006.

[24] J. O. Ugwuanyi, "Yield and protein quality of thermophilic Bacillus spp. biomass related to thermophilic aerobic digestion of agricultural wastes for animal feed supplementation," Bioresource Technology, vol. 99, no. 8, pp. 3279-3290, 2008.

[25] F. Federici, F. Fava, N. Kalogerakis, and D. Mantzavinos, "Valorisation of agro-industrial by-products, effluents and waste: concept, opportunities and the case of olive mill waste waters," Journal of Chemical Technology and Biotechnology, vol. 84, no. 6, pp. 895-900, 2009.

[26] Department of Environment, Industrial Processes \& The Environmental-Crude Palm Oil Industry, Ministry of Sciences, Technology and the Environment, Putrajaya, Malaysia, 1999.

[27] M. C. Hadiyanto, M. M. Azimatun Nur, and G. D. Hartano, "Cultivation of Chlorella sp. as biofuel sources in palm oil mill effluent (POME)," International Journal of Renewable Energy Development, vol. 1, no. 2, pp. 45-49, 2012.

[28] M. Christwardana and D. Soetrisnanto, "Phytoremediations of Palm Oil Mill Effluent (POME) by using aquatic plants and microalge for biomass production," Journal of Environmental Science and Technology, vol. 6, no. 2, pp. 79-90, 2013.

[29] C. S. Chooklin, S. Phertmean, B. Cheirsilp, S. Maneerat, and A. Saimmai, "Utilization of palm oil mill effluent as a novel and promising substrate for biosurfactant production by Nevskia ramosa NA3," Songklanakarin Journal of Science and Technology, vol. 35, no. 2, pp. 167-176, 2013.
[30] A. Salihu, M. Z. Alam, M. I. AbdulKarim, and H. M. Salleh, "Suitability of using palm oil mill effluent as a medium for lipase production," African Journal of Biotechnology, vol. 10, no. 11, pp. 2044-2052, 2011.

[31] K. Fadzilah and M. D. Mashitah, "Cellulases production in palm oil mill effluent: effect of aeration and agitation," Journal of Applied Sciences, vol. 10, no. 24, pp. 3307-3312, 2010.

[32] Y. P. Teoh and M. D. Mashitah, "Cellulase production by Pycnoporus sanguineus on oil palm residues through pretreatment and optimization study," Journal of Applied Sciences, vol. 10, no. 12, pp. 1036-1043, 2010.

[33] S. S. Rashid, M. Z. Alam, M. I. A. Karim, and M. H. Salleh, "Management of palm oil mill effluent through production of cellulases by filamentous fungi," World Journal of Microbiology and Biotechnology, vol. 25, no. 12, pp. 2219-2226, 2009.

[34] A. Sulaiman, M. R. Zakaria, M. A. Hassan, Y. Shirai, and Z. Busu, "Co-digestion of palm oil mill effluent and refined glycerin wash water for chemical oxygen demand removal and methane production," The American Journal of Environmental Sciences, vol. 5, pp. 639-646, 2009.

[35] T. Y. Wu, A. W. Mohammad, J. M. Jahim, and N. Anuar, "Investigations on protease production by a wild-type Aspergillus terreus strain using diluted retentate of pre-filtered palm oil mill effluent (POME) as substrate," Enzyme and Microbial Technology, vol. 39, no. 6, pp. 1223-1229, 2006.

[36] T. Y. Wu, A. W. Mohammad, J. M. Jahim, and N. Anuar, "Optimized reuse and bioconversion from retentate of prefiltered palm oil mill effluent (POME) into microbial protease by Aspergillus terreus using response surface methodology," Journal of Chemical Technology and Biotechnology, vol. 84, no. 9, pp. 1390-1396, 2009.

[37] P. Jamal, M. Z. Alam, M. Ramlan, M. Salleh, and M. M. Nadzir, "Screening of Aspergillus for citric acid production from Palm Oil Mill Effluent," Biotechnology, vol. 4, no. 4, pp. 275-278, 2005.

[38] M. S. Kalil, P. W. Kit, W. M. W. Yusoff, Y. Sadazo, and R. A. Rahman, "Direct fermentation of palm oil mill effluent to acetone- butanol-ehtanol by solvent producing Clostridia," Pakistan Journal of Biological Sciences, vol. 6, no. 14, pp. 12731275, 2003.

[39] C. P. Kurtzman and J. W. Fell, Eds., The Yeasts: A Taxonomic Study, Elsevier Science, Amsterdam, The Netherlands, 4th edition, 1998.

[40] M. Irfan, M. I. Nazir, M. Nadeem, M. Gulsher, Q. Syed, and S. Baig, "Optimization of process parameters for the production of single cell biomass of Candida utilis in solid state fermentation," The American-Eurasian Journal of Agriculture and Environmental Science, vol. 10, pp. 264-270, 2011.

[41] American Public Health Association (APHA), Standard Methods for the Examination of Water and Wastewater, American Public Health Association, Washington, DC, USA, 19th edition, 1995.

[42] J. Folch, M. Lees, and G. H. Sloane-Stanley, "A simple method for the isolation and purification of total lipides from animal tissues," The Journal of Biology and Chemistry, vol. 226, no. 1, pp. 497-509, 1957.

[43] W. Horwitz and G. W. Latimer Jr., Official Methods of Analysis of AOAC International, Revision 3, AOAC International, Gaithersburg, Md, USA, 18th edition, 2010.

[44] A. Walkley and I. A. Black, "An examination of the Degtjareff method for determining soil organic matter, and a proposed modification of the chromic acid titration method," Soil Science, vol. 37, pp. 29-38, 1945. 
[45] FAO/WHO, "Protein quality evaluation," Report of the Joint FAO/WHO Expert Consultation. FAO Food and Nutrition Paper 51, Food and Agriculture Organization of the United Nations, Rome, Italy, 1991.

[46] M. L. Hemming, "A viable solution to the palm oil effluent problem," in Proceedings of the Malaysian International Symposium on Palm Oil Processing and Marketing, D. A. Earp and W. Newall, Eds., pp. 79-95, Kuala Lumpur, Malaysia, June 1977.

[47] A. N. Ma, The Planters, Kuala Lumpur Innovations in Management of Palm Oil Mill Effluent, Palm Oil Research Institute of Malaysia (PORIM), 1999.

[48] P. F. Rupani, R. P. Singh, H. Ibrahim, and N. Esa, "Review of current Palm Oil Mill Effluent (POME) treatment methods: vermicomposting as a sustainable practice," World Applied Sciences Journal, vol. 11, pp. 70-81, 2010.

[49] International Finance Corporation (IFC), Environment, Health and Safety Guidelines for Vegetable Oil Processing, World Bank Group, 2007.

[50] N. Oswal, P. M. Sarma, S. S. Zinjarde, and A. Pant, "Palm oil mill effluent treatment by a tropical marine yeast," Bioresource Technology, vol. 85, no. 1, pp. 35-37, 2002.

[51] M. Z. Alam, P. Jamal, and M. M. Nadzir, "Bioconversion of palm oil mill effluent for citric acid production: statistical optimization of fermentation media and time by central composite design," World Journal of Microbiology and Biotechnology, vol. 24, no. 7, pp. 1177-1185, 2008.

[52] T. W. Barker and J. T. Worgan, "The utilisation of palm oil processing effluents as substrates for microbial protein production by the fungus Aspergillus oryzae," European Journal of Applied Microbiology and Biotechnology, vol. 11, no. 4, pp. 234-240, 1981.

[53] C. Saenge, B. Cheirsilp, T. T. Suksaroge, and T. Bourtoom, "Efficient concomitant production of lipids and carotenoids by oleaginous red yeast Rhodotorula glutinis cultured in palm oil mill effluent and application of lipids for biodiesel production," Biotechnology and Bioprocess Engineering, vol. 16, no. 1, pp. 2333, 2011.

[54] C. O. Nwuche, H. Aiyoaji, and J. C. Ogbonna, "Citric acid production from cellulase-digested palm oil mill effluent," Asian Journal of Biotechnology, vol. 5, no. 2, pp. 51-60, 2013. 

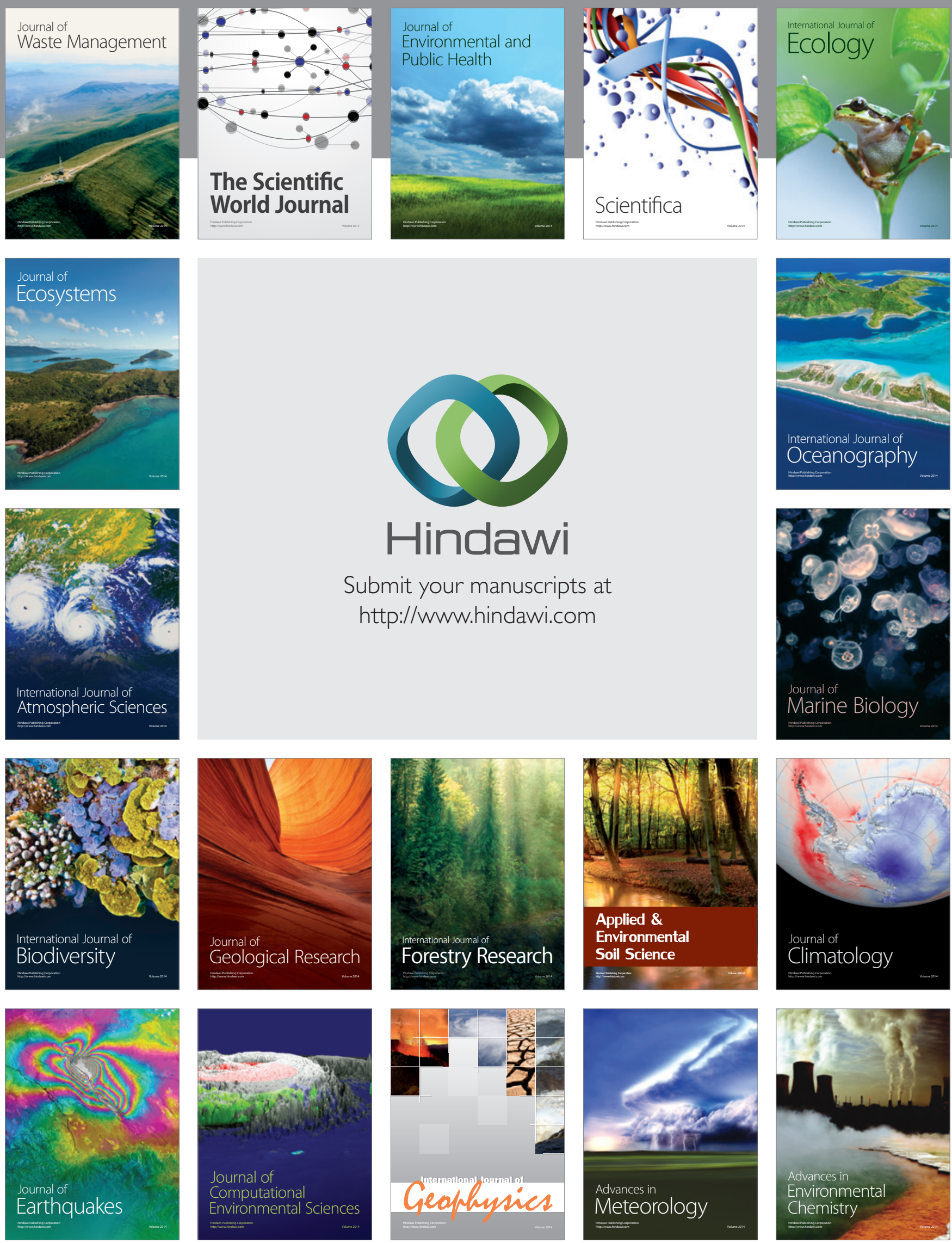